УДК 619:614.747:551.444:636.084.31

(C) 2014

Соколюк В. М., кандидат ветеринарних наук

Національний університет біоресурсів і природокористування України

\title{
ФОРМУВАННЯ СКЛАДУ ВОДИ, ЩО ВИКОРИСТОВУСТЬСЯ ДЛЯ НАПУВАННЯ ТВАРИН У ПІВДЕННІЙ БІОГЕОХІМІЧНІЙ ЗОНІ УКРАЇНИ
}

\section{Рецензент - доктор ветеринарних наук, професор Б. П. Киричко}

У статті проведений аналіз формування складу води, щуо використовується для напування тварин у господарствах південної біогеохімічної зони Украӥни. Представлено санітарно-гігієнічну оцінку джерел водопостачання; досліджено санітарно-гігієнічні показники безпечності та якості питної води. Встановлено, щуо зони санітарної охорони біля водозаборів у господарствах відсутні, порушуються також санітарно-гігієнічні вимоги, щзо й сприяло бактеріальному забрудненню підземних вод. Вивчено, щуо за хімічним складом досліджувана вода є прісною, з підвищзеною мінералізацією гідрокарбонатного класу групи натрію та кальиію другого типу. На основі результатів досліджень виявлено, щз вміст меркурію і мангану перевищував гранично допустимі концентраиії.

Ключові слова: джерела водопостачання, водоносний горизонт, якість води, хімічний склад води.

Постановка проблеми. Вода - важлива хімічна речовина на землі, середовище для природних i біологічних процесів. Вона забезпечує існування всього живого, функціонування процесів життєдіяльності організмів [1].

Недаремно один із семи мудреців давнини, основоположник грецької науки, відомий філософ, математик і астроном Фалес Мілетський (624-548 pp. до н. е.) вважав воду першоджерелом усього живого.

Найбільше води на нашій планеті належить світовому океану. Кров тварин (як і кров людини) за елементним складом досить близька до складу солей океанської води [4].

Водні ресурси нашої країни зосереджені у поверхневих водоймах, доповнюють їх підземні запаси води. Поверхневі води піддаються серйозному і практично постійному забрудненню стічними водами комунального сектора від промислових підприємств, сільськогосподарських угідь, сміттезвалищ.

Аналіз останніх досліджень і публікацій, у яких започатковано розв'язання проблеми. Для водопостачання населених пунктів, молочнотоварних ферм найбільш придатні підземні міжпластові артезіанські води, які перекриті зверху водонепроникними шарами (глини, кристалічні породи), що захищає їх від безпосереднього надходження забруднювальних речовин. Розповсюдження та специфіка складу природних підземних вод значною мірою визначається особливостями геологічної будови району $[5,11,12]$.

Вважається, що питна вода є одним із джерел надходження мінеральних речовин в організм тварин. Однак, залежно від якості вода, як складова біогеохімічного ланцюга, може впливати на стан здоров'я та продуктивність тварин.

Нестача або надлишок макро- і мікроелементів, відхилення концентрації цих елементів і речовин у воді від регламентованих величин у будьякій місцевості спричиняється не лише наслідками господарювання людиною, але й природними особливостями формування підземних вод $[1,9,10]$.

Мета дослідження - дослідити якість води та стан джерел водопостачання в господарствах південної біогеохімічної зони України.

Завдання дослідження - вивчити механізм формування складу води у південній біогеохімічній зоні.

Матеріал і методи дослідження. Дослідження проводили впродовж 2011-2012 рр. у господарствах Дніпропетровської та Кіровоградської областей: ТОВ «Фактор Д» Апостолівського, ДПДГ «Червоний Шахтар» Криворізького, ТОВ «Прогрес» Новгородського, ДПДГ «Елітне» (перше й друге відділення) Кіровоградського районів.

Проби води, що використовуються для напування тварин, у кожному з господарств відбирали із двох точок (свердловина і напувалка) посезонно, відповідно до методик [6].

Дослідження води проводили методом паралельних проб (n=3) у сертифікованих державних лабораторіях ветеринарної медицини. Співвідношення між іонами і хімічний склад вивчали, використовуючи формулу Курлова [8].

Дослідження якості води та інтерпретація отриманих результатів здійснювалися згідно 3 Державними санітарними нормами та правилами «Гігієнічні вимоги до води питної, призначеної для споживання людиною» (ДСан ПіН 2.2.4 - 171 - 10) [2]. 


\section{ВЕТЕРИНАРНА МЕДИЦИНА}

Результати дослідження. Під час визначення схеми сільськогосподарського водопостачання одним з основних питань був вибір вододжерел. Важливими показниками, що враховуються у виборі джерела водопостачання, $є$ :

- кількість і якість води у джерелі,

- віддаленість його від споживачів води,

- ступінь складності водозабірних, водоочисних і транспортних споруд,

- можливість забезпечення санітарної охорони джерела від забруднення.

У господарствах південної біогеохімічної зони України, в яких проводили дослідження, забезпечення молочнотоварних ферм i комплексів водою здійснюється, в основному, за рахунок централізованих систем водопостачання. Джерелами слугують міжпластові надра води в тріщинуватих докембрійських породах Українського кристалічного щита.

Поряд із цим, у двох дослідних господарствах $\epsilon$ поверхневі води. Водопостачання проводиться за рахунок Каховського водосховища (річка Дніпро) (табл. 1).

Поверхневі води більш захищені від поверхневих факторів, а тому зазвичай характеризуються стабільним хімічним складом. Хоча в окремих господарствах, де ми проводили дослідження, за рахунок природних факторів або антропогенного впливу ці води мають некондицій- ний склад (табл. 2).

Важливим $є$ застосування таких технологічних схем і санітарно-гігієнічних заходів, які б забезпечили формування якісної води підземних вододжерел.

У разі використання для господарськопитного водопостачання поверхневих джерел, вода проходить очищення і знезараження.

У зв'язку 3 цим у дослідженнях найбільше уваги приділялося вивченню формування якості води, що використовується для напування тварин, із підземних джерел водопостачання.

Глибина забору води з водоносних горизонтів у господарствах становила від 9 до 120 метрів. Системи водозабезпечення: артезіанські свердловини, шахтний колодязь, насосні станції, водопровідна мережа, згідно з технічною документацією, експлуатується протягом $25-40$ років.

Системи подачі води від водозабірних споруд до місць споживання виготовлені зі сталі, яка з часом піддається корозії, змащується, протікає і т. д.

Усі перераховані вище чинники можуть спричинити погіршення якості води, яку використовують у господарстві.

На артезіанські свердловини, за допомогою яких проводиться забір води із водоносних джерел, виготовлені паспорти.

Розміщені водозабірні свердловини, переважно, на території молочнотоварних ферм.

1. Характеристика джерел води, яку використовують для напування тварин у господарствах південної біогеохімічної зони Украӥни

\begin{tabular}{|c|c|c|}
\hline Назва господарства & $\begin{array}{c}\text { Глибина забору } \\
\text { води, м }\end{array}$ & Водоносні горизонти \\
\hline $\begin{array}{c}\text { TOВ «Прогрес»* } \\
\text { смт. Новгородка } \\
\text { Кіровоградська область }\end{array}$ & 120 & $\begin{array}{c}\text { Тріщинні води докембрійських } \\
\text { порід } \\
\text { Придніпровської височини }\end{array}$ \\
\hline $\begin{array}{c}\text { ДПДГ «Елітна» * } \\
\text { перше відділення } \\
\text { с. Созонівка } \\
\text { Кіровоградський р-н } \\
\text { Кіровоградська область } \\
\end{array}$ & 112 & $\begin{array}{c}\text { Тріщинні води докембрійських } \\
\text { порід } \\
\text { Придніпровської височини }\end{array}$ \\
\hline $\begin{array}{c}\text { ДПДГ «Елітне» * } \\
\text { друге відділення, } \\
\text { с. Степове } \\
\text { Кіровоградський р-н } \\
\text { Кіровоградська область }\end{array}$ & $\begin{array}{c}9 \\
\text { (шахтний } \\
\text { колодязь) }\end{array}$ & Грунтові води \\
\hline $\begin{array}{c}\text { ТОВ «Фактор Д»* } \\
\text { с. Нива Трудова, Апостольський р-н } \\
\text { Дніпропетроська область }\end{array}$ & поверхневі води & $\begin{array}{l}\text { Поверхневий стік, } \\
\text { грунтовий стік }\end{array}$ \\
\hline $\begin{array}{c}\text { ДПДГ «Червоний Шахтар»* } \\
\text { с. Вільне, Криворізький р-н } \\
\text { Дніпропетровська область }\end{array}$ & поверхневі води & $\begin{array}{c}\text { Поверхневий стік, } \\
\text { грунтовий стік }\end{array}$ \\
\hline
\end{tabular}

Примітка: * - джерела централізованого водопостачання Каховського водосховища 


\section{ВЕТЕРИНАРНА МЕДИЦИНА}

Iз метою забезпечення їх санітарноепідеміологічної надійності передбачаються 3они санітарної охорони. За результатами наших досліджень виявлено низку порушень санітарних вимог, а саме: територія вододжерела не пристосована, відсутні зелені насадження, не огороджена, відмічається вільний доступ як людей, так і тварин. Так, не витримані кордони поясів зон санітарної охорони, що запобігають забрудненню водоносного шару, який експлуатується.

Усі ці недоліки впливають на якість води, яку використовують у господарствах, що, в свою чергу, негативно позначається на здоров’ї тварин та якості продукції.
У результаті проведених досліджень отримані кількісні та якісні показники води 3 джерел водопостачання, які наведені у таблиці 2.

Органолептичні показники (запах, смак, присмак, забарвленість, каламутність) сприймаються органами чуття, - вони й визначають фізичні властивості води.

Запах води обумовлюється наявністю в ній органолептичних речовин (тваринного і рослинного походження) i зв'язаний 3 процесами їх розпаду. За наших досліджень суттєвих змін цього показника у пробах води, яку досліджували, не виявлено. Смак і присмак води також відповідали встановленим нормативам.

\section{2. Показники якості питної води для тварин із вододжерел південної біогеохімічної зони України, $M \pm m, n=3$}

\begin{tabular}{|c|c|c|c|c|c|c|c|}
\hline $\begin{array}{l}\text { № } \\
\Pi / \Pi \\
\end{array}$ & Показник & $\begin{array}{l}\text { Одиниці } \\
\text { виміру }\end{array}$ & гДК & Весна & Літо & Осінь & Зима \\
\hline 1 & $\begin{array}{c}\text { Запах t } 20{ }^{0} \mathrm{C}, \\
60{ }^{0} \mathrm{C}\end{array}$ & бали & $\leq 2$ & $1 / 2$ & $2 / 2$ & $1 / 2$ & $2 / 3$ \\
\hline 2 & Забарвленість & градуси & $\leq 20$ & $21 \pm 5,6$ & $18 \pm 4,4$ & $20 \pm 5,8$ & $23 \pm 4,4$ \\
\hline 3 & Каламутність & HOK & $\leq 1,0$ & $2,1 \pm 0,78$ & $1,1 \pm 0,1$ & $2,4 \pm 0,7$ & $2,2 \pm 0,66$ \\
\hline 4 & Смак та присмак & бали & $\leq 2$ & $1 \pm 0$ & $1 \pm 0$ & $1 \pm 0$ & $1 \pm 0$ \\
\hline 5 & Колі-індекс & - & - & $3 \pm 0$ & $3 \pm 0$ & $3 \pm 0$ & $3 \pm 0$ \\
\hline 6 & МАФАМ & $\mathrm{KУO} / \mathrm{cm}^{3}$ & $\begin{array}{c}\mathrm{He} \\
>100\end{array}$ & $115,2 \pm 5,03$ & $112,6 \pm 4,04$ & $110,1 \pm 2,14$ & $111,6 \pm 0,97$ \\
\hline 7 & Водн. показн. & $\mathrm{pH}$ & $6,5-8,5$ & $7,2 \pm 0$ & $7,3 \pm 0,13$ & $7,4 \pm 0,18$ & $7,2 \pm 0,03$ \\
\hline 8 & Азот. амон. & мгN/дм ${ }^{3}$ & $\leq 0,5$ & $0,14 \pm 0,03$ & $0,1 \pm 0,1$ & $0,1 \pm 0$ & $0,13 \pm 0,03$ \\
\hline 9 & Нітрати & мгN/дм ${ }^{3}$ & $\leq 50$ & $45 \pm 41,2$ & $36 \pm 35,5$ & $36 \pm 33,8$ & $61 \pm 58,5$ \\
\hline 10 & Нітрити & мгN/дм ${ }^{3}$ & $\leq 0,5$ & $0,02 \pm 0$ & $0,02 \pm 0$ & $0,02 \pm 0$ & $0,02 \pm 0$ \\
\hline 11 & Лужність & мг.екв/дм ${ }^{3}$ & $\leq 6,5$ & $8,0 \pm 1,12$ & $6,8, \pm 0,94$ & $6,3 \pm 1,02$ & $8,1 \pm 1,12$ \\
\hline 12 & $\begin{array}{c}\text { Загальна } \\
\text { жорсткість }\end{array}$ & мг.екв/дм ${ }^{3}$ & $\leq 7,0$ & $8,0 \pm 1,12$ & $6,8 \pm 0,94$ & $6,3 \pm 1,02$ & $8,1 \pm 1,12$ \\
\hline 13 & $\mathrm{Ca}^{2+}$ & мг/дм ${ }^{3}$ & $\leq 130$ & $139 \pm 21,3$ & $124 \pm 18,0$ & $112 \pm 19,7$ & $148 \pm 22,9$ \\
\hline 14 & $\mathrm{Mg}^{2+}$ & $\mathrm{Mг} / д \mathrm{M}^{3}$ & $\leq 80$ & $11,7 \pm 1,64$ & $8,1 \pm 1,1$ & $9,3 \pm 0,4$ & $9,7 \pm 2,11$ \\
\hline 15 & $\mathrm{~K}^{+}+\mathrm{Na}^{+}$ & $\mathrm{M \Gamma} /$ дм $^{3}$ & $\leq 200$ & $227 \pm 37,5$ & $282 \pm 144,7$ & $116 \pm 19,9$ & $111 \pm 16,5$ \\
\hline 16 & $\mathrm{HCO}_{3}^{-}$ & мг/дм ${ }^{3}$ & - & $480 \pm 67,4$ & $410 \pm 57,0$ & $380 \pm 61,0$ & $488 \pm 70,1$ \\
\hline 17 & Хлориди & мг/дм ${ }^{3}$ & $\leq 250$ & $149 \pm 47,0$ & $162 \pm 66,6$ & $161 \pm 70,3$ & $127 \pm 48,1$ \\
\hline 18 & Сульфати & мГ/дм ${ }^{3}$ & $\leq 250$ & $141 \pm 3,2$ & $276 \pm 89,8$ & $83 \pm 21,5$ & $73 \pm 3,3$ \\
\hline 19 & Мінерал. заг. & мг/дм ${ }^{3}$ & $\leq 1200$ & $1147 \pm 123,0$ & $932 \pm 273,2$ & $902 \pm 116,6$ & $972 \pm 155,5$ \\
\hline 20 & Сухий зал & мг/дм ${ }^{3}$ & $\leq 1000$ & $980 \pm 94,5$ & $1062 \pm 81,1$ & $709 \pm 124,9$ & $754 \pm 137,9$ \\
\hline 21 & Окис (пем) & $\mathrm{MГO} /$ дм $^{3}$ & $\leq 5,0$ & $3,0 \pm 0,6$ & $3,2 \pm 0,25$ & $4,2 \pm 1,4$ & $5,1 \pm 1,2$ \\
\hline 22 & $\mathrm{~Pb}^{2+}$ & мкг/дм ${ }^{3}$ & $\leq 10$ & $0,7 \pm 0,12$ & $0,9 \pm 0,56$ & $0,6 \pm 0,11$ & $0,5 \pm 0,2$ \\
\hline 23 & $\mathrm{Cd}^{2+}$ & мкг/дм ${ }^{3}$ & $\leq 1,0$ & $0,05 \pm 0,023$ & $0,04 \pm 0,02$ & $0,09 \pm 0,08$ & $0,25 \pm 0,08$ \\
\hline 24 & $\mathrm{As}^{2+}$ & мкг/дм ${ }^{3}$ & $\leq 10$ & $1,6 \pm 0,5$ & $1,4 \pm 0,16$ & $1,4 \pm 0,37$ & $2,0 \pm 0,1$ \\
\hline 25 & $\mathrm{Hg}^{2+}$ & мкг/дм ${ }^{3}$ & $\leq 0,5$ & $0,9 \pm, 006$ & $0,6 \pm 0,15$ & $0,4 \pm 0,06$ & $0,3 \pm 0,06$ \\
\hline 26 & $\mathrm{Cu}^{2+}$ & мкг/дм ${ }^{3}$ & $\leq 1000$ & $26 \pm 0,9$ & $18,9 \pm 3,0$ & $18 \pm 3,4$ & $4,2 \pm 5,0$ \\
\hline 27 & $\mathrm{Zn}^{2+}$ & мкг/дм ${ }^{3}$ & $\leq 1000$ & $16 \pm 3,5$ & $12 \pm 1,8$ & $22 \pm 1,8$ & $26 \pm 6,4$ \\
\hline 28 & $\mathrm{Fe}($ заг.) & мкг/дм ${ }^{3}$ & $\leq 200$ & $105 \pm 72,9$ & $181 \pm 49,5$ & $179 \pm 60,4$ & $223 \pm 80,8$ \\
\hline 29 & $\mathrm{Mn}^{2+}$ & мкг/дм ${ }^{3}$ & $\leq 50$ & $102 \pm 24,3$ & $135 \pm 29,3$ & $119 \pm 6,6$ & $146 \pm 22,3$ \\
\hline 30 & $\mathrm{Co}^{2+}$ & мкг/дм ${ }^{3}$ & $\leq 100$ & $9,6 \pm 1,2$ & $3,4 \pm 1,20$ & $5,0 \pm 1,0$ & $12,0 \pm 0,60$ \\
\hline
\end{tabular}




\section{ВЕТЕРИНАРНА МЕДИЦИНА}

Показником якості води $є$ забарвленість. У пробах води із господарств південного регіону вона була підвищена протягом року, окрім літа. Вважаємо, що це могло статися внаслідок потрапляння домішок органічного і мінерального походження. Не виключається можливість зміни забарвленості води внаслідок дії чинників хімічного або небактеріального походження. Каламутність води визначається рівнем іiі прозорості. За результатами досліджень цей показник коли-

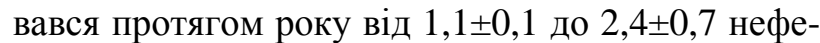
лометричних одиниць (за норми не $<1$ ). Каламутність знижує якість показників води, що також може сприяти розмноженню мікроорганізмів, у тому числі й патогенних.

Підтвердженням є результати санітарнобактеріологічних досліджень проб води. Кількість мезофільних аеробних i факультативноанаеробних мікроорганізмів (МАФАМ) була дещо підвищена й становила протягом року від $110,1 \pm 2,14$ до $115,2 \pm 5,03 \mathrm{KУО} / \mathrm{cm}^{3}$. Показники колі-індексу в межах норми.

Активна реакція води, яку використовують для напування тварин, у дослідних господарст-

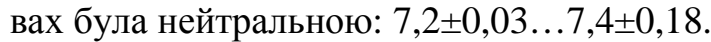

Азотовмісні сполуки (азот амонійний, нітрати, нітрити) утворюються у воді під час розкладу складних органічних речовин твариною або органічного походження білкових речовин, які потрапляють зі стічними водами. У досліджуваних пробах води виявлено лише сліди азоту амонійного і нітритів. Відмічали підвищену кількість у воді нітритів (солей азотної кислоти). Найбільша їх концент-

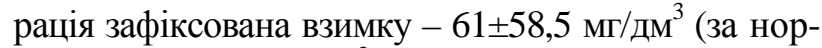
мами - до 50 мг/дм $\left.{ }^{3}\right)$. Встановлено, що причиною цього $\epsilon$ те, що в одному 3 господарств, де проводили дослідження, водозабір проводять із шахтного колодязя глибиною 9 метрів. Разом із грунтовими водами, які живлять це джерело, можливо, потрапляють стічні й побутові води; спостерігалася забрудненість внаслідок надмірного i нераціонального використання азотних мінеральних добрив.

Лужність води визначається сумою концентрації аніонів слабких кислот, передусім вугільної кислоти. У досліджуваних пробах води цей показник протягом року був підвищений і становив $6,8 \pm 0,94 \ldots 8,1 \pm 1,12$ мг.екв/дм ${ }^{3}$, за винятком осені -

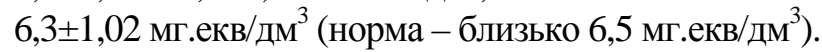
Це свідчить, що вода забруднюється органічними речовинами, здатними до гниття.

Жорсткість (твердість) води зумовлена наявністю в ній солей кальцію і магнію у вигляді сульфатів, хлоридів, карбонатів, гідрокарбонатів тощо. За результатами наших досліджень, цей

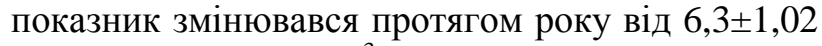
до $8,1 \pm 1,12$ мг.екв/дм ${ }^{3}$ і найвищим був навесні та взимку.

Аналогічна тенденція відмічалась і за вмісту у

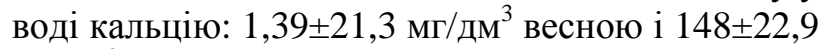
мг/дм ${ }^{3}$ - у зимовий період дослідження.

Вміст магнію у пробах води знаходився на ни-

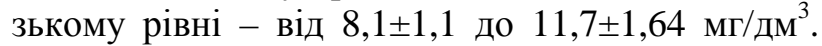
Концентрація калію та натрію перевищувала регламентовані величини у весняно-літній період.

Ключові аніони питної води (хлориди і сульфати) вимиваються із грунту. Останні можуть також утворюватися й за розкладу продуктів тваринного походження - білкових речовин амінокислоти, які містять сірку. У разі підвищеної концентрації сульфатів і хлоридів у воді погіршуються іiі основні якості (стає солоною, з гіркуватим присмаком), може порушуватися водносольовий баланс в організмі тварини. Вміст цих двох сполук у пробах води, яку ми досліджували, не перевищував регламентованих величин, за винятком літа: у цей період сульфати у воді дещо перевищували нормативи i становили $276 \pm 89,8$ мг/дм ${ }^{3}$ (норма - до 150 мг/дм³ ${ }^{3}$.

Іонний склад домішок води визначали за наявністю різних катіонів і аніонів. До головних іонів, які зумовлюють хімічний тип води, відносили: $\mathrm{HCO}_{3}^{-}, \mathrm{Ca}^{2+}, \mathrm{k}^{+}+\mathrm{Na}^{+}, \mathrm{SO}_{4}{ }^{2-}, \mathrm{CL}^{-}, \mathrm{Mg}^{2+}$.

Хімічний склад проб води 3 артезіанських свердловин дослідних господарств визначали за формулою Курлова. Склад головних іонів у воді змінювався залежно від сезону року. На основі цього було встановлено, що вода, яку використовують для напування тварин, в основному, належить до гідрокарбонатного класу, групи натрію, другого типу. В осінньо-зимовий період відбувалися певні зміни, зокрема води (гідрокарбонатна кальцієва другого типу). Розчинені у воді мінеральні речовини визначають загальну мінералізацію води, або несухий залишок. Результати досліджень води показують, що вміст солей у воді протягом року був стабільний. Лише влітку сухий залишок перевищував Державні стандарти й становив 1062 $\pm 81,1$ мг/дм ${ }^{3}$ (норма не більше 1200 мг/дм³ ${ }^{3}$.

Отже, після аналізу результатів можна стверджувати, що вода належить до прісних, із підвищеною мінералізацією.

Окиснюваність води зумовлюється наявністю в ній органічних речовин. За час дослідження показник перманганатної окиснюваності збіль-

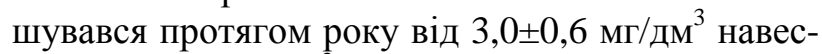
ні до $5,1 \pm 1,2$ мг/дм ${ }^{3}-$ взимку.

Біологічна роль мікроелементів в організмі тварин достатньо вивчена. Питна вода є одним із 


\section{ВЕТЕРИНАРНА МЕДИЦИНА}

джерел надходження в організм мінеральних речовин. Природні особливості формування артезіанських вод вивчали, враховуючи умови господарської діяльності, тобто, антропогенні чинники.

На основі результатів досліджень мікроелементного складу води, яку використовують для напування тварин у господарствах південної біогеохімічної зони України, було встановлено, що вміст плюмбуму, кадмію, арсену, купруму, цинку, кобальту був незначним. Концентрація меркурію перевищувала гранично допустимі концентрації у весняно-літній період і становила $0,6 \pm 0,15$ та $0,9 \pm 0,06$ мкг/дм ${ }^{3}$.

У пробах води, яку досліджували взимку, був незначно підвищений вміст феруму - до $223 \pm 80,8$ мкг/дм ${ }^{3}$ (за норми 200 мкг/дм ${ }^{3}$ ). Дослідженням води на вміст металу виявлено перевищення його у 2-3 рази за регламентованих величин. Це необхідно врахувати у підготовці води, яку використовують для напування тварин у господарстві.

Висновки: 1. Для напування тварин у господарствах південної біогеохімічної зони України використовують тріщинні води докембрійських порід і води централізованого водопостачання Каховського водосховища.

\section{БІБЛІОГРАФІЯ}

1. Бойко A. I. Загальна характеристика та особливості умов формування підземних вод на території Полтавської області як основного джерела питного водопостачання / А. І. Бойко // Вісник Полтавської державної аграрної академії. - Полтава, 2011. - № 2. - C. 169-173.

2. Гігієнічні вимоги до води питної, призначеної для споживання людиною. Дсан ПіН 2.2.4. 171-10 : Наказ МО3 України від 12.05.2012, №400 (зі змінами від 15.08.2011).

3. Голян $B$. A. Інституальне середовище водокористування: сучасний стан та механізми вдосконалення. - Луцьк : Твердиня, 2009. - 592 с.

4. Дерпгольи В. Ф. Мир воды. - Л. : Недра, 1979. - $254 \mathrm{c}$.

5. Копилевич В.A. К вопросу нормирования количества воды для разных видов водопотребления / В. А. Копилевич, Л. В. Войтенко // Вода і водоочисні технології. - 2010. - № 5-6. - С. 1719.

6. Методичний посібник (для проведення лабораторних занять 3 дисципліни «Гігієна тварин» для студентів факультету технології виробництва і переробки продукції тваринництва» /
2. Встановлено, що в господарствах, де проводилися дослідження, відсутні зони санітарної охорони підземних джерел водопостачання.

3. За результатами досліджень проб вод показники забарвленості й каламутності не відповідають регламентованим величинам.

4. Недотримання санітарно-гігієнічних вимог, незадовільний санітарно-технічний стан джерел водопостачання сприяють бактеріальному забрудненню питної води. Показник МАФАМ не відповідав санітарним нормам і правилам.

5. За хімічним складом досліджувана вода $\epsilon$ прісною, $з$ підвищеною мінералізацією гідрокарбонатного класу групи натрію та кальцію другого типу.

6. На основі результатів досліджень проб води встановлено, що вміст меркурію перевищував гранично допустимі концентрації у веснянолітній період, а кількість металу - у 2-3 рази протягом року.

Зважаючи на отримані результати, стверджуємо, що перспективним напрямом подальших досліджень є більш широке вивчення хімічного складу питної води для тварин у різних біогеохімічних зонах України.

М. О. Захаренко, В. М. Поляковський, Л. В. Шевченко [та ін.]. - К. : Вид-во ТОВ «НВП Інтерсервіс», 2013. - 220 с.

7. Стрикаленко T. Жизнь - вода, а вода жизнь / Т. Стрикаленко // Communty. - 2012, №2. - C. 14-16.

8. Хільчевський В.К. Основи гідрохімії: підручник / В. К. Хільчевський, В.І.Осадчий, С. М. Курило. - К. : Ніка-Центр, 2012. - 312 с.

9. Beede D. K. Assessment of water quality and nutrition for dairy cattle / D. K. Beede // Prov. Mid. South Ruminant Nutrition Conf. Arlington, TX.

10. Fiquepvon J. Land use impact on water quality: Valuny forest services in terms of the water supply sector / J. Fiquepron, S. Garcia, A. Stenger // Jornal of Environmental Management. - Vol. 126, 15 September, 2013. - P. 113-121.

11. Fujiwara $T$. Concept of on innovation water management system witch 128 ecentralized water reclamation and cascading material-cycle for agricultural ureas / T. Fujiwara // Water Sci Technol. 2012. - № 6. - P. 1171-1177.

12. Kalacz $R$. Higiena I dobrostan zwierzat gasnodarskich. - Wroclow, 2006. - 536 p. 